\title{
Meningkatkan Prestasi Belajar Siswa Pada Pelajaran Kewirausahaan Melalui Metode Mind Mapping
}

\author{
Batsir Podungge \\ SMKN Model Gorontalo \\ podunggebasir@gmail.com
}

\begin{abstract}
Abstrak
Hasil akhir dari penelitian ini adalah dengan permasalahan yang sangat spesifik sekali yaitu perilaku kurangnya Prestasi Belajar Siswa , maka dalam proses dan jangka waktu yang tidak pendek, metode pembelajaran peta konsep tersebut berdampak positif bagi siswa yaitu siswa yang tersebut bisa meningkatkan Prestasi Belajar Siswa. Terbukti pada perolehan hasil belajar siswa yang terus meningkat dari pra siklus hingga siklus 2. Pada pra siklus di mana pembelajaran masih menggunakan metode ceramah siswa yang mampu tuntas belajar hanya sejumlah 9 siswa, kemudian pada siklus 1 peneliti menerapkan metode pembelajaran peta konsep, dan hasil dari siklus 1 adalah terdapat 14siswa yang tuntas belajar. Pada siklus 2 masih dengan metode pembelajaran peta konsep maka seluruh siswa kelas XII TKJ yang berjumlah 21 siswa, yang dapat mencapai ketuntasan belajar adalah 19 siswa.
\end{abstract}

Kata Kunci: Prestasi Belajar, Metode Mind Mapping

\section{PENDAHULUAN}

Salah satu model pembelajaran berbisnis yang sering dilaksanakan oleh siswa SMK Negeri Tingkat keberhasilan suatu pendidikan adalah dilihat dari prestasi belajar siswa yang telah kita ketahui melalui rapor. Sehingga menyebabkan yang dinamakan suatu urutan perolehan. Sehingga terlihat yang dinamakan prestasi dari belajar itu sendiri. Prestasi Belajar yang bagus memungkinkan seorang anak bahwa dirinya adalah siswa yang berhasil dalam proses belajar tersebut. Sehubungan dengan itu, prestasi belajar siswa SMK Negeri Model Gorontalo tergolong rendah pada mata pelajaran Kewirausahaan Materi Prosedur Pengurusan Izin Usaha, maka peneliti yang dalam hal ini sebagai guru akan merubah metode ajar yang biasanya teacher centered menjadi metode ajar mind mapping. Metode Mind mapping atau peta pikiran adalah suatu tekhnik pembuatan catatan-catatan yang dapat digunakan pada situasi, kondisi tertentu, seperti dalam pembuatan perencanaan, penyelesaian masalah, membuat ringkasan, membuat struktur, pengumpulan ide-ide, untuk membuat catatan, kuliah, rapat, debat dan wawancara.

Oleh karena itu, dalam penelitian ini akan mengambil judul "Upaya Meningkatkan Prestasi Belajar Siswa Pada Pelajaran Kewirausahaan Materi Prosedur Pengurusan Izin Usaha Melalui Metode Mind mapping pada Siswa Kelas XII TKJ SMK Negeri Model Gorontalo Tahun Ajaran 2017/2018"

\section{METODE PENELITIAN}

Rancangan penelitian menurut Masnur (Muslich, 2010), rencana dan struktur penelitian yang disusun sedemikian rupa sehingga peneliti akan memperoleh jawaban untuk pertanyaan penelitiannya. Proses pelaksanaan tindakan dilaksanakan secara bertahap sampai penelitian ini berhasil. Prosedur tindakan dimulai dari (1) perencanaan tindakan, (2) pelaksanaan tindakan, (3) pengamatan dan evaluasi serta (4) analisis dan refleksi.

Lokasi penelitian adalah di SMK Negeri Model Gorontalo. Subjek penelitian adalah siswa Kelas XII TKJ SMK Negeri Model Gorontalo, sejumlah 21. Subyek penelitian ini mempunyai 
kemampuan yang berbeda-beda yakni ada sebagaian siswa yang mempunyai kemampuan sedang, rendah, serta sangat rendah

Penelitian ini menggunakan Penelitian Tindakan Kelas (PTK). Menurut Tim Pelatih Proyek PGSM, PTK adalah suatu bentuk kajian yang bersifat reflektif oleh pelaku tindakan yang dilakukan untuk meningkatkan kemantapan rasional dari tindakan mereka dalam melaksanakan tugas,memperdalam pemahaman terhadap tindakan-tindakan yang dilakukan itu,serta memperbaiki kondisi dimana praktek pembelajaran tersebut dilakukan (dalam (Mukhlis, 2000).

Teknik analisis data yang digunakan secara deskreptif yaitu hanya mengumpulkan data yang diperoleh melalui pengamatan dan tes hasil belajar di susun, dijelaskan, dan akhirnya di analisis dalam tiga tahapan yaitu:

1. Reduksi Data

Reduksi data merupakan suatu proses pemilihan, pemusatan dan perbaikan pada penyederhanaan data. Pada tahap reduksi data pengamatan terhadap proses pembelajaran Kewirausahaan Materi Prosedur Pengurusan Izin Usaha .

2. Display Data (Penyajian Data )

Data yang diperoleh melalui pengamatan dan tes hasil belajar berbentuk tabel dan kalimat sederhana setiap putaran.

\section{HASIL PENELITIAN}

Pengumpulan data dilakukan pada tanggal 7 November 2017 sampai dengan 12 Desember 2017 , dengan perincian kegiatan sebagai berikut :

Tabel 2 Waktu dan Kegiatan Penelitian

\begin{tabular}{ll}
\hline \multicolumn{1}{c}{ Waktu } & \multicolumn{1}{c}{ Kegiatan } \\
\hline 7-9 November 2017 & Mencari refrensi untuk rencana penelitian \\
\hline 11 November 2017 & $\begin{array}{l}\text { Berkomunikasi dengan kepala sekolah dan } \\
\text { wali Kelas XII TKJ }\end{array}$ \\
\hline 12 November 2017 & $\begin{array}{l}\text { Pelaksanaan pembelajaran Kewirausahaan } \\
\text { Materi Prosedur Pengurusan Izin Usaha } \\
\text { melalui merode ceramah (pra siklus) }\end{array}$ \\
\hline 14-16 November 2017 & Mengumpulkan data : prestasi belajar siswa \\
\hline 18 November 2017 & Menyusun proposal PTK \\
\hline 20-26 November 2017 & Pelaksanaan penelitian siklus I \\
\hline 28 November -3 Desember & Pelaksanaan penelitian siklus II \\
\hline 5-12 Desember 2017 & Menyusun hasil penelitian \\
\hline
\end{tabular}

\section{Hasil Penelitian Pra Siklus}

Peneliti mulai melaksanakan kegiatan penelitian pada tanggal 7 November 2017 dengan mencari refrensi untuk rencana penelitian. Kemudian di lanjutkan dengan berkomunikasi dengan kepala sekolah dan wali Kelas XII TKJ pada tanggal 11 November 2017 . Lalu melaksanakan Kegiatan pra siklus pada tanggal 12 November 2017 dengan melaksanakan pembelajaran Kewirausahaan Materi Prosedur Pengurusan Izin Usaha melalui merode ceramah. Kegiatan pra siklus ini bertujuan untuk mengetahui kemampuan awal yang dimiliki oleh siswa dalam Kewirausahaan Materi Prosedur Pengurusan Izin Usaha sebelum di terapkan metode Pembelajaran Peta Konsep. 
1. Tahap Perencanaan Pra Siklus
a) Membuat instrument penelitian yang terdiri dari lembar observasi prestasi belajar siswa, pedoman wawancara, dan penilaian hasil belajar
b) Membuat RPP

\section{Pelaksanaan}

Kegiatan pra siklus dilaksanakan pada tanggal 12 November 2017 dengan menggunakan metode yang biasa di lakukan yaitu metode konvensional (ceramah kemudian praktek) dalam pembelajaran Kewirausahaan Materi Prosedur Pengurusan Izin Usaha . Kegiatan pra siklus ini dilaksanakan dengan alokasi waktu 1 X 45 menit (1 Jam Pelajaran) atau 1 kali pertemuan. Adapun pelaksanaan dari kegiatan pra siklus dimulai dengan kegiatan awal, selanjutnya kegiatan inti dan terakhir kegiatan penutup.

1. Kegiatan Awal
a) Guru mengucapkan salam ( displin )
b) Guru memimpin doa bersama dengan khusyu (religious )
c) Guru mempresensi kehadiran siswa (displin)
d) Guru melakukan kegiatan apersepsi ( disiplin)

2. Kegiatan Inti
a) Guru membiasakan menyampaikan kompetensi yang ingin dicapai ( disiplin)
b) Guru menyajikan materi Kewirausahaan Materi Prosedur Pengurusan Izin Usaha sehingga peserta didik dapat mengetahui lebih mendalam dan meluas dari sesuatu yang dipelajarinya( memiliki rasa ingin tahu )
c) Guru memberikan tugas untuk Kewirausahaan Materi Prosedur Pengurusan Izin Usaha .

3. Kegiatan Penutup
a) Guru memberikan refleksi kepada siswa ( tanggung jawab ) pada saat proses pembelajaran telah usai.
b) Guru menyampaikan tindak lanjut hasil tes bersama siswa dan Guru bertanggung jawab membuat kesimpulan akhir ( bekerja sama dan tanggung jawab ).
c) Guru membiasakan menutup pembelajaran dengan mengucapkan salam ( disiplin )

4. Pengamatan

Pada kegiatan observasi awal ini bertujuan untuk mengetahui kondisi dalam Kelas XII TKJ dan kemampuan siswa dalam Kewirausahaan Materi Prosedur Pengurusan Izin Usaha Kemudian dari hasil tindakan pra siklus serta pengamatan langsung dalam kegiatan pembelajaran menunjukkan bahwa rata-rata siswa dalam pembelajaran masih belum memiliki kemampuan yang baik dalam Kewirausahaan Materi Prosedur Pengurusan Izin Usaha. Hal ini didukung dengan perolehan hasil belajar pada pembelajaran Kewirausahaan Materi Prosedur Pengurusan Izin Usaha pada kegiatan pra siklus yang belum mencapai standart KKM yang telah ditentukan oleh sekolah yaitu skor 75 untuk mata pelajaran Kewirausahaan Materi Prosedur Pengurusan Izin Usaha.

Berdasarkan hasil penelitian kegiatan pada kondisi awal di atas maka dapat diketahui bahwa prestasi belajar siswa pada siswa Kelas XII TKJ SMK Negeri Model Gorontalo pada materi Kewirausahaan Materi Prosedur Pengurusan Izin Usaha masih rendah. Pada pra siklus dengan menggunakan ceramah siswa yang tuntas belajar hanya mencapai 8 siswa.

\section{Hasil Penelitian Siklus I}

\section{Perencanaan}

Pada perencanaan tindakan pertama ini peneliti menerapkan metode Pembelajaran peta konsep dengan maksud membantu siswa yang memiliki kemampuan secara heterogen dalam 


$$
\begin{aligned}
& \text { Volume }: 04 \\
& \text { Nomor }: 01 \\
& \text { Bulan }: \text { Januari } \\
& \text { Tahun : 2018http } \\
& \text { //ejurnal.pps.ung.ac.id/index.php/AKSARA/index }
\end{aligned}
$$

memahami mata pelajaran Kewirausahaan Materi Prosedur Pengurusan Izin Usaha pada aspek Kewirausahaan Materi Prosedur Pengurusan Izin Usaha .

Siklus ini memfokuskan pembahasan tentang Kewirausahaan Materi Prosedur Pengurusan Izin Usaha Adapun perencanaan dalam siklus ini sebagai berikut:

1) menyampaikan kompetensi yang ingin dicapai

2) Guru memberi penjelasan mengenai model peta konsep (mind mapping).

3) Guru menjelaskan kriteria penilaian peta konsep yang dibuat.

4) Guru membagi siswa dalam kelompok kecil yang terdiri atas 6 anggota untuk membedakan Kewirausahaan Materi Prosedur Pengurusan Izin Usaha dengan surat dinas.

5) Guru membantu menggali daya kreatifitas siswa untuk Kewirausahaan Materi Prosedur Pengurusan Izin Usaha secara kelompok

6) Guru memberi penguatan terhadap simpulan dan refleksi yang diberikan oleh siswa

2. Pelaksanan

Pelaksanaan siklus I memberikan pembelajaran Kewirausahaan Materi Prosedur Pengurusan Izin Usaha melalui metode Pembelajaran peta konsep yaitu pembelajaran menggunakan media grafis dua dimensi yang berfungsi mengorganisasikan dan merepresentasikan suatu pengetahuan, biasanya berupa beberapa gambar kotak atau lingkaran berisikan tulisan terkait mengenai konsep yang dipelajari. Kegiatan pembelajaran ini dilaksanakan pada 20 sampai 26 November 2017 dengan alokasi waktu masing-masing pertemuan 2 X45 menit yaitu 2 JP. Adapun perincian pelaksanakan tindakan ini sebagai berikut:

1) Pertemuan Ke 1

Pada pertemuan ke I ini terdapat kegiatan awal, inti dan penutup. Adapun rincian dari kegiatan awal dari pertemuan ke I adalah :

(1) Kegiatan Awal

a. Mengecek kesiapan siswa

b. Memotivasi siswa sebagai kegiatan apersepsi

c. Menyampaikan tujuan pembelajaran.

d. Guru memberikan gambaran singkat menganai pertemuan pada siklus I.

(2) Kegiatan Inti

a. Guru memberi penjelasan mengenai materi Kewirausahaan Materi Prosedur Pengurusan Izin Usaha

b. Guru dan siswa melakukan tanya jawab yang berkaitan dengan materi pembelajaran.

c. Guru memberi penjelasan mengenai model peta konsep (mind mapping).

d. Guru menjelaskan kriteria penilaian peta konsep yang dibuat.

e. Guru membagi siswa dalam kelompok kecil yang terdiri atas 6 anggota untuk mengidentifikasi perbedaan Kewirausahaan Materi Prosedur Pengurusan Izin Usaha dengan surat dinas

f. Guru membantu menggali daya kreatifitas siswa untuk Kewirausahaan Materi Prosedur Pengurusan Izin Usaha kepada teman yang berada di kelompok lain

g. Masing-masing siswa membuat peta konsep (mind mappig) secara kreatif .

(3) Kegiatan Penutup

a. Guru mengumpulkan pekerjaan siswa untuk dibagikan kembali pada pertemuan selanjutnya.

b. Siswa secara bersama-sama menyimpulkan butir-butir pembelajaran atas bimbingan guru. 
c. Siswa mengadakan refleksi dengan memberikan tugas Kewirausahaan Materi Prosedur Pengurusan Izin Usaha yang baik dan benar.

d. Guru memberi penguatan terhadap simpulan dan refleksi yang diberikan oleh siswa.

2) Pertemuan Ke 2

Pada pertemuan ke 2 juga meliputi kegiatan awal, inti dan penutup. Adapun rincian dari kegiatan awal dari pertemuan ke 2adalah :

(1) Kegiatan Awal

a. Pengucapan sapaan salam

b. Doa bersama

c. Absensi kehadiran siswa di dalam Kelas XII TKJ

d. Kegiatan meregangkan otot-otot dengan sedikit pemanasan ringan di dalam Kelas XII TKJ

(2) Kegiatan Inti

a. Guru memberi penjelasan mengenai materi Kewirausahaan Materi Prosedur Pengurusan Izin Usaha

b. Guru dan siswa melakukan tanya jawab yang berkaitan dengan materi pembelajaran.

c. Guru memberi penjelasan mengenai model peta konsep (mind mapping).

d. Guru menjelaskan kriteria penilaian peta konsep yang dibuat.

e. Guru membagi siswa dalam kelompok kecil yang terdiri atas 6 anggota untuk mengidentifikasi perbedaan Kewirausahaan Materi Prosedur Pengurusan Izin Usaha dengan surat dinas

f. Guru membantu menggali daya kreatifitas siswa untuk Kewirausahaan Materi Prosedur Pengurusan Izin Usaha kepada teman yang berada di kelompok lain

g. Masing-masing siswa membuat peta konsep (mind mappig) secara kreatif

(3) Kegiatan Penutup

a. Guru mengumpulkan pekerjaan siswa untuk dibagikan kembali pada pertemuan selanjutnya.

b. Siswa secara bersama-sama menyimpulkan butir-butir pembelajaran atas bimbingan guru.

c. Siswa mengadakan refleksi dengan memberikan tugas Kewirausahaan Materi Prosedur Pengurusan Izin Usaha yang baik dan benar.

d. Guru memberi penguatan terhadap simpulan dan refleksi yang diberikan oleh siswa

3. Pengamatan

Selama kegiatan pembelajaran berlangsung, peneliti bertindak sebagai observer yang bertugas mengamati kegiatan pembelajaran dengan mengisi lembar observasi yang telah disusun sebelum melaksanakan kegiatan penelitian. Hal ini dilakukan untuk mengetahui peningkatan kemampuan siswa dalam Kewirausahaan Materi Prosedur Pengurusan Izin Usaha pada mata pelajaran Kewirausahaan Materi Prosedur Pengurusan Izin Usaha. Pada kegiatan belajar mengajar ini guru menggunakan metode Pembelajaran peta konsep untuk membantu siswa dalam meningkatkan prestasi belajar siswa.

Penilaian kegiatan pembelajaran Kewirausahaan Materi Prosedur Pengurusan Izin Usaha ini terbagi dalam 2 komponen, yaitu: (1) Siswa mampu Mengidentifikasi struktur morfologi dan anatomi batang tumbuhan. (2) Siswa mampu membedakan struktur morfologi batang tumbuhan dikotil dan monokotil.

\section{Refleksi}

Hasil dari refleksi pada siklus ke I ini adalah meskipun masih terdapat beberapa kesulitan yang dihadapi oleh siswa dalam Kewirausahaan Materi Prosedur Pengurusan Izin Usaha, akan 


$$
\begin{aligned}
& \text { Volume }: 04 \\
& \text { Nomor }: 01 \\
& \text { Bulan }: \text { Januari } \\
& \text { Tahun : 2018http } \\
& \text { //ejurnal.pps.ung.ac.id/index.php/AKSARA/index }
\end{aligned}
$$

tetapi penerapan metode Pembelajaran Peta Konsep pada siklus I ini berjalan dengan cukup baik. Hal ini terlihat pada antusiasme yang ditunjukkan oleh siswa dalam mengikuti pembelajaran serta penguasaan meteri.

\section{Hasil Penelitian Siklus II}

\section{Perencanaan}

Perencanaan siklus II memfokuskan pembahasan pada pokok bahasan Kewirausahaan Materi Prosedur Pengurusan Izin Usaha yaitu siswa di nyatakan mampu dalam Kewirausahaan Materi Prosedur Pengurusan Izin Usaha jika sudah memenuhi kriteria sebagai berikut :

1) Siswa mampu Mengidentifikasi struktur morfologi dan anatomi batang tumbuhan

2) Siswa mampu membedakan struktur morfologi batang tumbuhan dikotil dan monokotil Adapun perencanaan dalam siklus II ini adalah sebagai berikut:

a. menyampaikan kompetensi yang ingin dicapai

b. Guru memberi penjelasan mengenai model peta konsep (mind mapping).

c. Guru menjelaskan kriteria penilaian peta konsep yang dibuat.

d. Guru membagi siswa dalam kelompok kecil yang terdiri atas 6 anggota untuk Kewirausahaan Materi Prosedur Pengurusan Izin Usaha

e. Guru membantu menggali daya kreatifitas siswa untuk Kewirausahaan Materi Prosedur Pengurusan Izin Usaha secara kelompok

f. Guru memberi penguatan terhadap simpulan dan refleksi yang diberikan oleh siswa.

2. Pelaksanan

Pelaksanaan siklus II sama dengan

pelaksanaan pada siklus I yaitu memberikan pembelajaran Kewirausahaan Materi Prosedur Pengurusan Izin Usaha dengan metode pembelajaran peta konsep. Kegiatan pembelajaran ini dilaksanakan pada 28 November - 3 Desember 2017 dengan alokasi waktu masing-masing pertemuan 2 X45 menit yaitu 2 JP. Adapun perincian pelaksanakan tindakan ini sebagai berikut:

1) Pertemuan Ke 3

Pada pertemuan ke I ini terdapat kegiatan awal, inti dan penutup. Adapun rincian dari kegiatan awal dari pertemuan ke 3adalah :

(1) Kegiatan Awal

a. Mengecek kesiapan siswa

b. Memotivasi siswa sebagai kegiatan apersepsi

c. Menyampaikan tujuan pembelajaran.

d. Guru memberikan gambaran singkat menganai pertemuan pada siklus I.

(2) Kegiatan Inti

a. Guru memberi penjelasan mengenai materi Kewirausahaan Materi Prosedur Pengurusan Izin Usaha

b. Guru dan siswa melakukan tanya jawab yang berkaitan dengan materi pembelajaran.

c. Guru memberi penjelasan mengenai model peta konsep (mind mapping).

d. Guru menjelaskan kriteria penilaian peta konsep yang dibuat.

e. Guru membagi siswa dalam kelompok kecil yang terdiri atas 6 anggota untuk Kewirausahaan Materi Prosedur Pengurusan Izin Usaha

f. Guru membantu menggali daya kreatifitas siswa untuk Kewirausahaan Materi Prosedur Pengurusan Izin Usaha kepada teman yang berada di kelompok lain

g. Masing-masing siswa membuat peta konsep (mind mappig) secara kreatif

(3) Kegiatan Penutup 


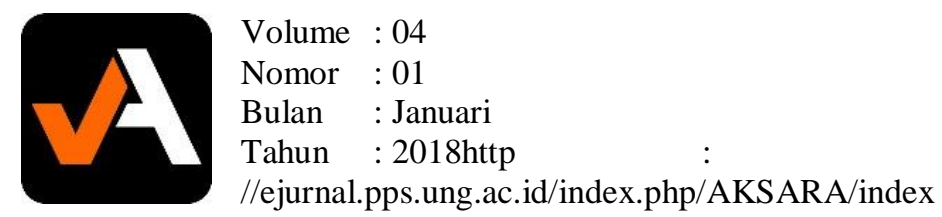

a. Guru mengumpulkan pekerjaan siswa untuk dibagikan kembali pada pertemuan selanjutnya.

b. Siswa secara bersama-sama menyimpulkan butir-butir pembelajaran atas bimbingan guru.

c. Siswa mengadakan refleksi dengan memberikan tugas Kewirausahaan Materi Prosedur Pengurusan Izin Usaha yang baik dan benar

d. Guru memberi penguatan terhadap simpulan dan refleksi yang diberikan oleh siswa.

2) Pertemuan Ke 4

Pada pertemuan ke 4 juga meliputi kegiatan awal, inti dan penutup. Adapun rincian dari kegiatan awal dari pertemuan ke 4 adalah :

(1) Kegiatan Awal

a. Pengucapan sapaan sala

b. Doa bersama

c. Absensi kehadiran siswa di dalam Kelas XII TKJ

d. Kegiatan meregangkan otot-otot dengan sedikit pemanasan ringan di dalam Kelas XII TKJ

(2) Kegiatan Inti

a. Guru memberi penjelasan mengenai materi Kewirausahaan Materi Prosedur Pengurusan Izin Usaha.

b. Guru dan siswa melakukan tanya jawab yang berkaitan dengan materi pembelajaran.

c. Guru memberi penjelasan mengenai model peta konsep (mind mapping).

d. Guru menjelaskan kriteria penilaian peta konsep yang dibuat.

e. Guru membagi siswa dalam kelompok kecil yang terdiri atas 6 anggota untuk Kewirausahaan Materi Prosedur Pengurusan Izin Usaha.

f. Guru membantu menggali daya kreatifitas siswa untuk Kewirausahaan Materi Prosedur Pengurusan Izin Usaha kepada teman yang berada di kelompok lain.

g. Masing-masing siswa membuat peta konsep (mind mappig) secara kreatif.

(3) Kegiatan Penutup

a. Guru mengumpulkan pekerjaan siswa untuk dibagikan kembali pada pertemuan selanjutnya.

b. Siswa secara bersama-sama menyimpulkan butir-butir pembelajaran atas bimbingan guru.

c. Siswa mengadakan refleksi dengan memberikan tugas Kewirausahaan Materi Prosedur Pengurusan Izin Usaha yang baik dan benar.

3. Pengamatan

Pembelajaran menyelesaikan siklus akuntansi perusahaan dagang melalui metode pembelajaran peta konsep meningkat kondusifitas belajarnya.

4. Refleksi

Penerapan model pembelajaran peta konsep banyak menuntut peran aktif siswa baik dalam kerja kelompok maupun yang bersifat individu.Hal ini dibuktikan dengan perolehan hasil belajar siswa yang mengalami peningkatan dimulai dari pelaksanaan pra siklus sampai pada siklus II sebagaimana dijabarkan dalam tabel perolehan nilai dibawah ini. 
Tabel 1 Data Hasil Belajar Siswa Dalam Kewirausahaan Materi Prosedur Pengurusan Izin Usaha Melalui Metode Peta Konsep Pada Siklus II

\begin{tabular}{clcc}
\hline No & \multicolumn{1}{c}{ Nama } & Nilai & Keterangan \\
\hline 1 & Abd. Kadir Alimullah & 80 & Tuntas \\
\hline 2 & Abd. Rasyid Panini & 80 & Tuntas \\
\hline 3 & Abdul Rizky Sabihi & 82 & Tuntas \\
\hline 4 & Ahmad Adam & 85 & Tuntas \\
\hline 5 & Ayub Hamdata & 90 & Tidak Tuntas \\
\hline 6 & Dimas Aditya Panigoro & 60 & Tuntas \\
\hline 7 & Egrina Ibrahim & 88 & Tuntas \\
\hline 8 & Fitriyani Tanini & 80 & Tuntas \\
\hline 9 & Fitriyani Ramadhanti Poha & 87 & Tuntas \\
\hline 10 & Indriani Makuta & 85 & Tuntas \\
\hline 11 & Ismiyati Rahman & 65 & Tuntas \\
\hline 12 & Lolasri Ibrahim & 80 & Tuntas \\
\hline 13 & Meilandi Musa & 88 & Tuntas \\
\hline 14 & Mof. Rifaldi Lasimpala & 85 & Tuntas \\
\hline 15 & Moh. Riski Ibrahim & 80 & Tuntas \\
\hline 16 & Nandra Audila D. Botutihe & 79 & Tuntas \\
\hline 17 & Nuriyanti Santili & 88 & Tuntas \\
\hline 18 & Nurlisa Sune & 81 & Tuntas \\
\hline 19 & Rizaldi H. Yusuf & 80 & Tuntas \\
\hline 20 & Sintia Hasan & 90 & \\
\hline 21 & Yulan Kasim & 90 & siswa \\
\hline Jumlah siswa tuntas belajar & & \\
\hline
\end{tabular}

\section{PENUTUP}

Pada siklus ke II ini terdiri dari kegiatan perencanaan, pengamatan, dan refleksi tindakan.Pada siklus ini pelaksanaan metode Pembelajaran peta konsep juga sama seperti yang di terapkan pada siklus I, dan hasil dari metode penelitian yang sudah di laksanakan menunjukkan peningkatan kondusifitas belajar dengan metode Pembelajaran peta konsep pada materi Kewirausahaan Materi Prosedur Pengurusan Izin Usaha pada mata pelajaran Kewirausahaan Materi Prosedur Pengurusan Izin Usaha Kelas XII TKJ SMK Negeri Model Gorontalo. Pada siklus 2 ini 19 siswa mampu mencapai tuntas belajar.

\section{DAFTAR RUJUKAN}

Mukhlis, A. (Ed.). (2000). Penelitian Tindakan Kelas. Makalah Panitia Pelatihan

Penulisan Karya Ilmiah untuk Guru-guru se-Kabupaten Tuban.

Muslich, M. (2010). Text Book Writing. Jakarta: Ar-Ruzz Media. 